\title{
TOTAL HEMOSIT, GLUKOSA DAN SURVIVAL RATE UDANG MANTIS (Harpiosquilla raphidea) PASCA TRANSPORTASI DENGAN DUA SISTEM YANG BERBEDA
}

\author{
TOTAL HEMOSIT, GLUCOSE AND SURVIVAL RATE MANTIS SHRIMP \\ (Harpiosquilla raphidea) POST TRANSPORTATION \\ WITH TWO DIFFERENT SYSTEM
}

\author{
M. Yusuf Arifin ${ }^{1}$, Eddy Supriyono ${ }^{2}$ dan Widanarni ${ }^{2}$ \\ ${ }^{1}$ Mahasiswa Pasca Sarjana Program Studi Ilmu Akuakultur Institut Pertanian Bogor, \\ ${ }^{2}$ Departemen Budidaya Perairan, Fakultas Perikanan dan Ilmu Kelautan, IPB Bogor \\ Jl. Agatis, Kampus IPB Dramaga Bogor, Telp. 0251-86287552 \\ Email: yusuf_arifin88@yahoo.com
}

Diterima tanggal: 7 Juli 2014, diterima setelah perbaikan: 28 Juli 2014, disetujui tanggal: 31 Juli 2014

\begin{abstract}
ABSTRAK
Udang mantis (Harpiosquilla raphidea) merupakan salah satu krustasea yang bernilai ekonomis tinggi. Saat ditransportasi udang cenderung mengalami stres, oleh sebab itu dibutuhkan teknologi transportasi untuk meminimalisir tingkat stres. Tujuan dari penelitian ini untuk membandingkan efek stres pada udang mantis dari dua metode transportasi yang berbeda yaitu, transportasi sistem kering dan transportasi basah. Respon stress yang diamati adalah jumlah total hemosit (THC), konsentrasi glukosa dan kelangsungan hidup. Sampel diambil pada waktu 0, 1, 3, 6, 12, 24, 72, 168 dan 336 jam pasca transportasi. Data dianalisis dengan Uji-T. Hasil penelitian ini menunjukkan bahwa jumlah THC lebih tinggi pada sistem kering dibanding sistem basah terutama pada jam ke-72. Konsentrasi glukosa dengan sistem basah lebih tinggi dari sistem kering pada jam ke-0 dan jam ke-24. Tingkat kelangsungan hidup lebih tinggi pada sistem kering dari pada sistem basah. Dari penelitian ini disimpulkan bahwa transportasi sistem kering lebih baik karena menghasilkan respon stress yang lebih rendah dan waktu pulih yang lebih cepat.
\end{abstract}

Kata kunci: Mantis, THC, glukosa, stres, transportasi

\section{ABSTRACT}

Mantis shrimp (Harpiosquilla raphidea) is a crustaceans of high economic value. Currently transported shrimp tend experience stress, therefore the technology needed to minimize transport stress levels. Objec of this study to compare the effects of stress on mantis shrimp from the two different methods of transport, namely, the transport system wet and dry. Stress response observed was THC, concentration glucose and survival. Samples were taken at time 0, 1, 3, 6, 12, 24, 72, 168 and 336 hours post-transport. Data analyzed by T-test. Results of this study indicate that the amount of THC was higher in the dry than the wet system especially at 72nd. Concentration of glucose with a wet system higher the dried at 0 and 24 hour. Survival rate higher in the dry system of the wet. This study suggests that dry transport system better because it produces a lower stress response and a faster recovery.

Keywords: Mantis, THC, glucose, stress, transportation

\section{PENDAHULUAN}

Udang Mantis (Harpiosquilla raphidea) merupakan salah satu crustacea yang memiliki bentuk fisik menyerupai belalang sembah (manthis). Nama daerah untuk udang ini yaitu pangko, udang ketak, atau udang nenek. Istilah udang ronggeng digunakan untuk nama dagang dan nama dalam bahasa Indonesia, sedangkan dalam bahasa Inggris udang ini dikenal dengan nama manthis shrimp (Mashar, 2011; Dini, Kasim \& Palupi, 2013). Udang ini memiliki nilai ekonomis tinggi, harga per-ekor udang mantis untuk ekspor ke Hongkong dan Taiwan berkisar

Total Hemosit, Glukosa dan Survival Rate Udang Mantis (Harpiosquilla raphidea) Pasca Transportasi dengan Dua Sistem yang Berbeda - M. Yusuf Arifin, Eddy Supriyono dan Widanarni 
antara Rp 20.000 sampai Rp. 70.000 untuk kelas A (> $25 \mathrm{~cm})$, dan kelas B $(20-25 \mathrm{~cm})$, dengan volume ekspor berkisar antara 10-15 ton/minggu (Kompas, 2004). Berdasarkan data DKP Kabupaten Tanjung Jabung Barat (2010) hasil tangkapan udang mantis terus meningkat dari 1.300 .000 ekor pada tahun 2003, meningkat menjadi 2.500 .000 ekor di tahun 2009. Meningkatnya hasil tangkapan tersebut dikhawatirkan akan menurunkan populasi udang mantis di alam. Salah satu solusi yang dapat ditempuh untuk mengantisipasi hal tersebut adalah melalui kegiatan budidaya.

Transportasi benih/bibit udang merupakan langkah awal dalam kegiatan budidaya pembesaran udang. Adanya jarak dan waktu yang dibutuhkan selama proses transportasi dapat menyebabkan stres pada benih. Menurut Verghese (2003), transportasi merupakan salah satu penyebab stress pada proses pengangkutan lobster hidup. Lebih lanjut menurut Lorenzon, Giulianini, Martinis, \& Ferrero (2007) transportasi dapat meyebabkan stres dan mempengaruhi kondisi fisiologis pada lobster Homarus americanus.

Respon stres yang disebabkan oleh perubahan kondisi lingkungan dapat ditandai dengan adanya perubahan fisiologis dalam jangka pendek atau jangka panjang yang menyebabkan pengalihan energy sumberdaya untuk proses vital, proses tersebut dapat merusak atau mengancam kondisi homeostasis (Buchanan, 2000). Dalam kondisi stres terjadi realokasi energy metabolik aktivitas investasi (seperti pertumbuhan dan reproduksi) menjadi aktivitas untuk memperbaiki homeostasi, seperti respirasi, pergerakan, regulasi hidromineral dan perbaikan jaringan. Kebutuhan energi untuk memperbaiki homeostasi selama stres dipenuhi oleh proses glikogenolisis dan glukoneogenesis yang menghasilkan glukosa (Hastuti, Mokoginta, Dana \& Sutardi, 2004).

Stres berpengaruh pada sistem kekebalan ikan melalui jalur metabolik (Hastuti et al., 2004; Leland, Butchera, Broadhursta, Patersonc \& Mayer, 2013; Yeh, Li, Tsui, Lin \& Chen, 2010). Hemosit memainkan peranan penting dalam sistem imun crustacea. Menurut Maharani, Sunarti, Triastuti \& Juniastuti (2009), komposisi hemolymph dapat diukur dan dapat digunakan sebagai penilaian kesehatan crustacea melalui karakteristik dan aktivitas sistem pertahanan terhadap agen infeksius yang diperankan oleh hemosit. Hemosit berperan dalam fagositosis, enkapsulasi, degranulasi dan agregasi nodular terhadap patogen atau partikel asing. Menurut Lorenzon, Francese, Smith \& Ferrero (2001), pengaruh transportasi pada jumlah total hemosit (THC) pada Cancer pagurus diduga menggambarkan imunosupresi yang mungkin menyediakan celah bagi patogen oportunis untuk masuk kedalam tubuh. Lebih lanjut menurut Lorenzon, Giulianini, Libralato \& Martinis (2008), transportasi menyebabkan terjadinya penurunan THC yang signifikan, terutama pada transportasi sistem basah.

Transportasi sistem basah umumnya digunakan untuk distribusi jarak dekat dengan waktu yang relatif singkat. Menurut Hasan (2007) transportasi ikan hidup menggunakan media air untuk jarak jauh tidak efektif karena memerlukan biaya pengangkutan yang besar, kapasitas angkut kecil dan resiko kematian yang tinggi. Dalam sistem tertutup dengan kepadatan tinggi, kematian benih disebabkan oleh rendahnya oksigen terlarut (DO), akumulasi amoniak dan $\mathrm{CO}_{2}$, suhu yang tinggi, dan terjadinya kanibalisme karena saat transportasi berlangsung biota tidak diberi makan. Transportasi sistem kering mempunyai beberapa kelebihan, yaitu dapat mengurangi stres, menurunkan kecepatan metabolisme dan penggunaan oksigen, mengurangi mortalitas akibat perlakuan fisik, tidak mengeluarkan feses dan tidak perlu media air sehingga daya angkut lebih besar (Berka, 1986). Lebih lanjut menurut Lorenzon et al. (2008), transportasi dengan media air dapat menyebabkan kematian yang lebih tinggi dibandingkan dengan transportasi tanpa air.

Sampai saat ini penelitian tentang transportasi ikan hidup sistem basah sudah sering dilakukan, begitupun dengan sistem kering untuk kebutuhan konsumsi. Namun demikian, penelitian transportasi sistem kering untuk kebutuhan budidaya belum pernah dilakukan baik itu ukuran benih untuk pembesaran maupun calon induk. Khusus untuk udang mantis, secara ilmiah memang belum pernah diteliti, baik itu transportasi sistem basah maupun sistem kering. Oleh karena itu perlu kiranya dilakukan penelitian tentang transportasi udang mantis untuk kebutuhan budidaya dengan mengkaji respon stress pasca transportasi. 


\section{BAHAN DAN METODE}

Penelitian dilakukan selama 3 bulan terhitung dari bulan April hingga Juni 2014 yang berlangsung di Laboratorium Lingkungan Departemen Budidaya Perairan, Fakultas Perikanan dan Ilmu Kelautan, Institut Pertanian Bogor. Perlakuan yang sudah dilakukan adalah 2 jenis metode transportasi yaitu transportasi sistem kering tanpa media pengisi yang diinjeksi oksigen (selanjutnya disebut sebagai TKTM-O ${ }_{2}$ ), dan transportasi sistem basah dengan media air (selanjutnya disebut sebagai TB).

Air yang digunakan adalah air laut dengan salinitas $20 \%$, suhu $30^{\circ} \mathrm{C}, \mathrm{pH} 7$, dan DO > $5 \mathrm{mg} / \mathrm{l}$. Nilai parameter tersebut digunakan atas dasar hasil penelitian Mashar dan Wardiatno (2011) bahwa perairan yang sesuai untuk kehidupan udang mantis adalah dengan salinitas $19-28 \%$, suhu 30 - $33^{\circ} \mathrm{C}, \mathrm{pH} 7,5-8,0$, dan DO 5,2 - 8,0 mg/L.

Untuk pengangkutan ikan hidup sistem kering digunakan selongsong yang terbuat dari plastik mika, dimana selongsong tersebut berfungsi sebagai tempat penyimpanan udang. Wadah kemasan yang digunakan berupa box styrofoam dengan ukuran $40 \times 25 \times 15 \mathrm{~cm}$ dengan ketebalan 2,5 $\mathrm{cm}$.

Biota uji yang digunakan adalah udang mantis hasil tangkapan nelayan di Kabupaten Tanjung, Jabung Timur, Propinsi Jambi. Udang mantis terlebih dahulu diadaptasikan di dalam wadah pemeliharaan selama 7 hari sebelum perlakuan. Udang mantis uji yang digunakan adalah yang sehat, bugar, tidak cacat fisik, dan tidak sedang dalam fase ganti kulit (moulting). Udang yang digunakan berukuran panjang $15-18 \mathrm{~cm}$ dengan bobot 82-87 gram/ekor.

\subsection{Prosedur Penelitian}

Uji transportasi dilakukan selama 12 jam. Untuk perlakuan transportasi sistem kering, terlebih dahulu udang mantis dibius menggunakan metode penurunan suhu secara bertahap. Suhu pembiusan yang digunakan mengacu dari hasil penelitian Suparno, Wibowo, Suryaningrum \& Suherman (1994), dan Wibowo, Setiabudi, Suryaningrum \& Sudrajat (1994) yaitu dengan suhu $15^{\circ} \mathrm{C}$. Penurunan suhu dilakukan dengan kecepatan 5$10^{\circ} \mathrm{C} / \mathrm{jam}$ atau $0,4-0,8^{\circ} \mathrm{C} / \mathrm{menit}$ (Suryaningrum, Utomo \& Wibowo, 2005). Udang yang telah terbius di masukkan ke dalam selongsong yang terbuat dari plastik mika, kemudian disusun sejajar di dalam kotak styrofoam yang sebelumnya diberi lubang untuk sirkulasi oksigen. Pada bagian samping kiri dan kanan susunan udang diberi sekat sebagai tempat es batu yang berfungsi untuk mempertahankan suhu agar udang tetap pingsan. Styrofoam ditutup dan kemudian di lakban. Selanjutnya dimasukkan kedalam kantong plastik, kemudian dilakukan injeksi oksigen dan kantong plastik diikat dengan karet.

Untuk perlakuan sistem basah, benih udang dikemas ke dalam kantong plastik yang diisi air laut salinitas 25\% yang sebelumnya sudah diaerasi selama 24 jam. Selanjutnya dilakukan injeksi oksigen murni dengan perbandingan 1:2, dimana 1 bagian air dan 2 bagian oksigen.

\subsection{Pembugaran Udang}

Setelah dilakukan transportasi selama 12 jam, kemasan dibuka dan udang mantis dianginanginkan selama 3-5 menit (Suwandi, Novriani \& Nurjanah, 2008). Hal ini bertujuan agar gas amonia yang terbentuk selama transportasi menguap. Selanjutnya udang mantis dimasukkan kedalam akuarium dengan ketinggian air setengah dari badan udang (Frose, 1997; Suryaningrum, Syamidi \& Ikasari, 2007). Suhu air awal disamakan dengan suhu didalam kemasan saat dibongkar. Suhu air dinaikkan perlahan dengan kecepatan $5-10{ }^{\circ} \mathrm{C} /$ jam hingga suhu air mencapai $30^{\circ} \mathrm{C}$. Penambahan air juga dilakukan perlahan seiring dengan kenaikan suhu hingga mencapai ketinggian $30 \mathrm{~cm}$.

\subsection{Pemeliharaan Pasca Transportasi}

Udang mantis ditebar ke dalam akuarium dengan ukuran 100x50x60 cm sebanyak 10 ekor. Menurut Mashar dan Wardiatno (2011), habitat udang mantis (Harpiosguilla raphidea) adalah dasar perairan berlumpur dengan tipe substrat lempung berpasir, dan udang mantis cenderung berlindung dalam lubang di dalam substrat lumpur dengan diameter dan kedalaman lubang yang bervariasi sesuai dengan ukurannya. Lebih lanjut menurut Dini et.al (2013) substrat pasir dan pasir berlempung merupakan habitat yang sesuai bagi kehidupan udang mantis. Oleh karena itu untuk memberikan kenyamanan pada mantis, maka setiap akuarium diberi shelter dari pipa paralon sebagai tempat berlindung mantis. Pemeliharaan udang dilakukan selama 14 hari yang diberi pakan berupa ikan rucah dengan frekuensi tiga sampai empat kali/hari 


\subsection{Parameter Uji}

Pengambilan hemolim mantis diambil pada bagian titik kaki jalan paling belakang dekat abdomen. Pengamatan konsentrasi glukosa dan THC dilakukan pada udang normal (sebagai nilai basal), dan udang perlakuan yaitu pada jam ke 0 (saat pembongkaran), jam ke 1, 3, 6, 12, 24, 72, 168 dan 336 pasca transportasi.

Parameter uji pada penelitian ini dapat dilihat pada Tabel 1 di bawah ini.

Tabel 1. Parameter uji penelitian Table 1. Parameters of test research

\begin{tabular}{cll}
\hline No & Parameter & Metode \\
\hline 1 & THC & Blaxhall \& Daisley (1973) \\
2 & Glukosa & Calorimetric \\
3 & Survival Rate & Zonneveld \& Huisman (1991)
\end{tabular}

Sumber: Hasil studi literatur

\subsection{Jumlah Total Hemosit (THC)}

Hemolim diambil sebanyak $0,1 \mathrm{ml}$ di bagian pangkal kaki jalan dengan syringe $1 \mathrm{ml}$ yang sudah berisi antikoagulan Na-sitrat sebanyak $0,1 \mathrm{ml}$, kemudian dihomogenkan selama 5 menit. Tetesan pertama hemolim pada syringe dibuang, selanjutnya diteteskan ke haemositometer dan dihitung jumlah selnya per ml di bawah mikroskop cahaya dengan perbesaran 40 kali. Rumus yang digunakan menurut Blaxhall and Daishley (1973), yaitu; Total Hemosit $=[($ rata-rata total sel $) x$ (1/volume kotak besar) $x$ (faktor pengencer)].

\subsection{Kadar Glukosa}

Kadar glukosa diukur dengan metode Wedemeyer \& Yasutake (1977). Sampel hemolim yang ditampung dalam tabung evendop disentrifuse selama 10 menit dengan kecepatan putaran 1000 rpm untuk memisahkan plasma hemolim. Selanjutnya plasma hemolim sebanyak $0.5 \mu \mathrm{l}$ ditambahkan ke dalam $3,5 \mathrm{ml}$ reagen warna orthotoluidin dalam asam asetat glasial. Campuran tersebut dimasukkan dalam air mendidih selama 10 menit. Setelah didinginkan dalam suhu ruang, konsentrasi glukosa hemolim diukur dengan spektrofotometer pada panjang gelombang $635 \mathrm{~nm}$. Selanjutnya nilai absorbansinya dikonversi menjadi kadar glukosa hemolim dalam mg/100 ml. Kadar glukosa hemolim dihitung berdasarkan persamaan yang dikemukakan oleh Wedemeyer dan Yasutake (1977).

$$
G D=\frac{A b s S p}{A b s S t} x G S t
$$

Keterangan:

GD = Konsentrasi glukosa hemolim $(\mathrm{mg} / \mathrm{dl})$

AbsSp = Absorbansi sampel

AbsSt = Absorbansi standat

GSt $=$ Konsentrasi glukosa standar $(\mathrm{mg} / \mathrm{dl})$

\subsection{Tingkat Kelangsungan Hidup}

Data kelangsungan hidup didapatkan dengan pengamatan jumlah udang yang hidup. Kelangsungan hidup atau Survival Rate (SR), dihitung dengan rumus;

$$
S R=\frac{N t}{N 0} \times 100 \%
$$

\section{Keterangan : \\ SR = tingkat kelangsungan hidup (\%) \\ $\mathrm{Nt} \quad=$ jumlah individu pada akhir perlakuan (hari ke-t) \\ No = jumlah individu pada awal perlakuan (hari ke-0)}

\subsection{Analisis Data}

Data yang diperoleh akan ditabulasi ke dalam Microsoft excel dan selanjutnya dianalisis secara statistik dengan SPSS.

\section{HASIL DAN PEMBAHASAN}

Sebelum dilakukan uji terhadap beberapa parameter pasca transportasi, dilakukan pengambilan hemolim pada udang yang tanpa diberi perlakuan, dimana data tersebut digunakan sebagai parameter acuan. Nilai gambaran hemolin udang mantis pada kondisi normal disajikan pada pada Tabel 2.

Tabel 2. Gambaran hemolim udang mantis pada kondisi normal.

Table 2. Overview hemolim mantis shrimp under normal conditions

\begin{tabular}{ll} 
Parameter & Nilai konsentrasi \\
\hline THC & $5.1 \pm 0.2 \times 10^{7} \mathrm{Cell} / \mathrm{ml}$ \\
Glukosa & $37.24 \pm 0.8 \mathrm{mg} / \mathrm{dl}$ \\
\hline
\end{tabular}

Sumber: Hasil analisis laboratorium 


\subsection{Gambaran Hemolim Saat Pembongkaran}

Pada saat pembongkaran yaitu setelah 12 jam transportasi, dilakukan pengambilan sampel hemolim pada setiap perlakuan.

Dari Tabel 3 terlihat bahwa saat pembongkaran jumlah total hemosit (THC) pada perlakuan TKTM-O2 $\left(1,97 \pm 0,15 \times 10^{7} \mathrm{Cell} / \mathrm{ml}\right)$ lebih tinggi dari perlakuan TB $\left(0,93 \pm 4,30 \times 10^{7} \mathrm{Cell} / \mathrm{ml}\right)$, namun keduanya lebih rendah dari jumlah THC pada kondisi normal $\left(5,1 \pm 0,2 \times 10^{7} \mathrm{Cell} / \mathrm{ml}\right)$.

Tabel 3. Gambaran hemolim udang mantis saat pembongkaran (jam ke-0).

Table 3. Overview hemolim mantis shrimp when demolition (h-0)

\begin{tabular}{lcc}
\hline Parameter & TKTM-O2 & TB \\
\hline THC & $1,97 \pm 0,15 \mathrm{Cell} / \mathrm{ml}^{\text {a }}$ & $0,93 \pm 0,15 \mathrm{Cell} / \mathrm{ml}^{\text {a }}$ \\
Glukosa & $46,88 \pm 10,12 \mathrm{mg} / \mathrm{dl}^{\text {a }}$ & $68,37 \pm 5,26 \mathrm{mg} / \mathrm{dl}^{\text {b }}$ \\
\hline
\end{tabular}

Sumber: Hasil analisis laboratorium

Rendahnya total hemosit pada kedua perlakuan menunjukkan bahwa udang dalam kondisi stress yang disebabkan oleh paparan udara dan suhu saat transportasi. Namun demikian jumlah total hemosit pada perlakuan $\mathrm{TKTM}-\mathrm{O}_{2}$ lebih tinggi dari perlakuan TB. Hal ini menunjukkan bahwa sistem transportasi mempengaruhi jumlah total hemosit udang mantis, dimana perlakuan $\mathrm{TKTM}^{-\mathrm{O}_{2}}$ mampu meminimalisir tingkat stress dibandingkan perlakuan TB. Menurut Lorenzon et al. (2008), transportasi menyebabkan terjadinya penurunan THC yang signifikan, terutama pada transportasi sistem basah. Penurunan THC pada krustasea sering disebabkan oleh kondisi stres; khususnya dikarenakan adanya peningkatan suhu dan lamanya pemaparan udara (Le Moullac, Soyez, Sauliner, Ansquer, Avarre \& Levy, 1998). Lebih lanjut diungkapkan oleh Cheng, Lu \& Chen (2005) yang mengamati pengaruh suhu terhadap respon imun udang vannamei, menunjukkan bahwa perlakuan suhu 24,28 dan $32^{\circ} \mathrm{C}$ selama 24 sampai 96 jam akan menurunkan total hemosit sekitar $12-16 \%$. Pendapat tersebut sesuai dengan hasil penelitian ini, dimana pada saat pembongkaran suhu air pada perlakuan TB mencapai $30 \pm 0.58^{\circ} \mathrm{C}$.

Untuk konsentrasi glukosa pada saat pembongkaran (Tabel 3) terjadi perbedaan yang signifikan $(\mathrm{P}<0,05)$ antara kedua perlakuan, dimana perlakuan TB $(68,37 \pm 5,26 \mathrm{mg} / \mathrm{dl})$ lebih tinggi dari pada perlakuan TKTM-O $_{2}(46,88 \pm$
10,12 mg/dl). Tingginya konsentrasi glukosa pada perlakuan TB disebabkan adanya kebutuhan energy yang meningkat saat udang dalam kondisi stress. Hasil penelitian ini sesuai dengan hasil penelitian yang dilakukan oleh Lorenzon et al. (2008), bahwa kadar glukosa darah pada Cancer pagurus meningkat pada saat kedatangan awal. Lebih lanjut dikatakan bahwa kadar glukosa darah pada $C$. pagurus tergantung pada sistem transportasi, dimana peningkatan konsentrasi glukosa berkaitan dengan mobilisasi penyimpanan energi dalam kondisi stres karena ketersediaan $\mathrm{O}_{2}$ rendah. Pendapat tersebut sesuai dengan hasil penelitian ini, dimana pada saat pembongkaran konsentrasi oksigen terlarut didalam air media pengangkutan cukup rendah yaitu sebesar 4,6 \pm $0,44 \mathrm{mg} / \mathrm{L}$.

\subsection{Jumlah Total Hemosit (THC) Pasca Transportasi}

Hemosit memainkan peranan penting dalam sistem imun krustasea. Hemosit berperan dalam fagositosis, enkapsulasi, degranulasi dan agregasinodular terhadap pathogen atau partikel asing (Sahoo, Das, Mohanty, Pilai \& Mohanty, 2008). Stres berpengaruh pada sistem kekebalan ikan melalui jalur metabolik (Hastuti et al., 2004; Yeh et al., 2010; Leland et al., 2013;). Selanjutnya Menurut Maharani et al. (2009), komposisi hemolymph dapat diukur dan dapat digunakan sebagai penilaian kesehatan crustacea melalui karakteristik dan aktivitas sistem pertahanan terhadap agen infeksius yang diperankan oleh hemosit.

Dari Gambar 1 terlihat bahwa jumlah total hemosit pada kedua perlakuan meningkat mendekati nilai normal, namun pada jam ke-72 terjadi perbedaan secara signifikan $(\mathrm{P}<0.05)$, dimana nilai THC pada perlakuan TKTM-O2 $\left(4,77 \pm 0,312 \times 10^{7} \mathrm{Cell} / \mathrm{ml}\right)$ lebih tinggi dari pada perlakuan TB $(2,93$ $\left.\pm 0,512 \times 10^{7} \mathrm{Cell} / \mathrm{ml}\right)$. Hal tersebut menunjukkan bahwa udang pada perlakuan TKTM-O2 lebih cepat pulih mendekati nilai normal dari pada perlakuan TB, dimana udang pada perlakuan TB $\left(4.97 \pm 0.76 \times 10^{7} \mathrm{Cell} / \mathrm{ml}\right)$ baru mendekati nilai normal pada jam ke-168.

Rendahnya total hemosit sebelum jam ke-72 menunjukkan bahwa udang dalam kondisi stress yang disebabkan oleh paparan udara dan suhu saat transportasi serta udang masih dalam proses adaptasi dengan lingkungan yang baru. Menurut 
Jussila (1997), beberapa faktor yang mempengaruhi total hemosit antara lain intervensi pathogen, mekanisme molting dan kondisi lingkungan. Penurunan THC pada krustasea sering disebabkan oleh kondisi stres; khususnya, dikarenakan adanya peningkatan suhu dan lamanya pemaparan udara (Le Moullac et al., 1998). Lebih lanjut diungkapkan oleh Cheng et al. (2005) yang mengamati pengaruh suhu terhadap respon imun udang vannamei, menunjukkan bahwa perlakuan suhu akan menurunkan total hemosit sekitar 12$16 \%$.

Hasil penelitian ini menunjukkan bahwa sistem transportasi menyebabkan stress yang ditandai dengan menurunya jumlah total hemosit. Hal ini sesuai dengan pendapat Lorenzon et al. (2001), Pengaruh transportasi pada THC di $C$. pagurus diduga menggambarkan imunosupresi yang mungkin menyediakan celah bagi patogen oportunis untuk masuk ke dalam tubuh. Lebih lanjut menurut Lorenzon et al. (2008), transportasi menyebabkan terjadinya penurunan THC yang signifikan, terutama pada transportasi sistem basah. Dari pendapat yang sama dikatakan bahwa transportasi $C$. pagurus mengakibatkan adanya respon stres yang berujung pada perubahan fisiologi dan imunokompetensi yang berakibat mempengaruhi kemampuannya untuk menahan infeksi bakteri.

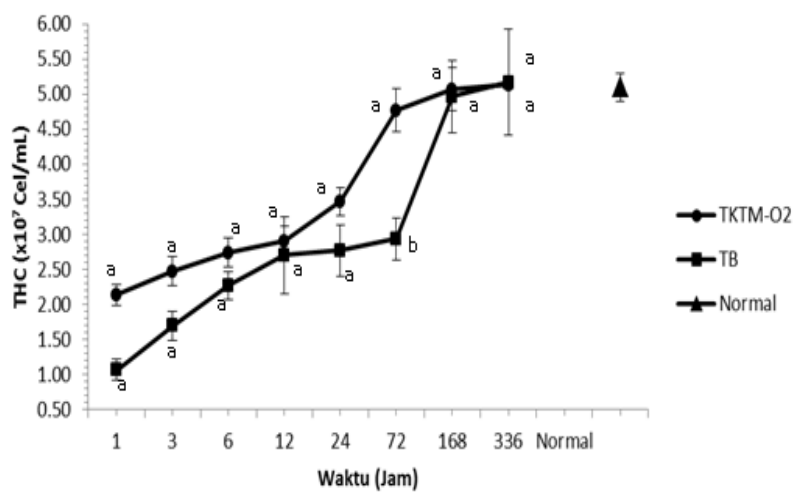

Gambar 1. Jumlah total hemosit (THC) udang mantis pasca transportasi. Huruf berbeda pada waktu yang sama menunjukkan berbeda nyata $(\mathrm{P}<0,05)$. Nilai dinyatakan \pm sebagai standar error.

Figure 1. The total number hemosit (THC) mantis shrimp post-transport. Different letters at the same time showed significantly different $(P<0.05)$. Values are expressed as \pm standard error. Sumber: Hasil pengolahan data

\subsection{Konsentrasi Glukosa Pasca Transportasi}

Pada Gambar 2 terlihat bahwa dari jam ke-3 konsentrasi glukosa cenderung terus menurun mendekati nilai normal, namun pada jam ke-24 secara signifikan $(\mathrm{P}<0,05)$ konsentrasi glukosa untuk perlakuan TB $(62,70 \pm 4,31 \mathrm{mg} / \mathrm{dl})$ lebih tinggi dari perlakuan TKTM-O2 (50,63 $\pm 3,02$ $\mathrm{mg} / \mathrm{dl}$ ), dimana pada jam tersebut konsentrasi glukosa pada perlakuan TKTM-O ${ }_{2}$ lebih cepat turun mendekati nilai pada kondisi normal, sedangkan perlakuan TB baru mendekati kondisi normal pada jam ke-72.

Kondisi tersebut menunjukkan bahwa udang pada perlakuan $\mathrm{TKTM}^{-\mathrm{O}_{2}}$ telah melewati fase stress pada jam ke-24, dimana pada waktu tersebut udang tidak lagi memanfaatkan glukosa di dalam hemolim sebagai sumber energi, sehingga konsentrasi glukosa akan menurun ke titik normal. Mengatasi kondisi stres memerlukan kemampuan hewan untuk menyediakan cukup energi di dalam jaringan untuk menghadapi beban allostatic yang dapat diperoleh dari glukosa dan protein (McEwen dan Wingfield, 2003). Peningkatan konsentrasi glukosa berkaitan dengan mobilisasi penyimpanan energi dalam kondisi stres sebagai sumber bahan bakar untuk metabolisme anaerob menghasilkan produksi dan akumulasi laktat (Lorenzon et al., 2008).

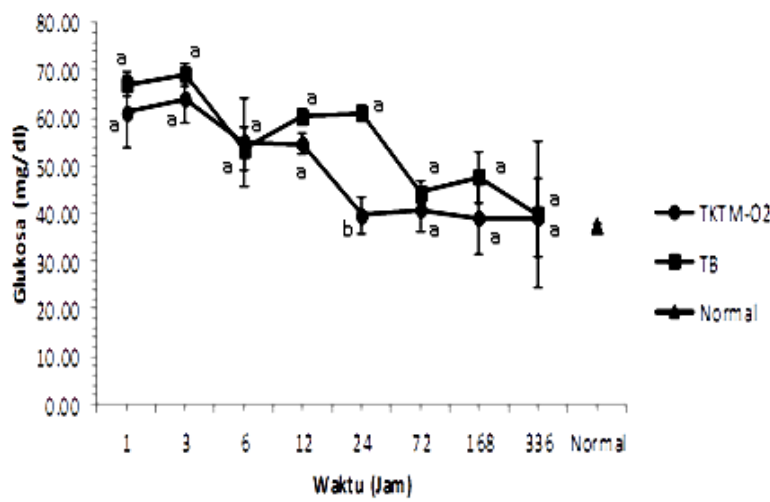

Gambar 2. Konsentrasi glukosa udang mantis pasca transportasi. Huruf berbeda pada jam yang sama menunjukkan berbeda nyata $(\mathrm{P}<0,05)$. Nilai dinyatakan \pm sebagai standar error.

Figure 2. Concentrations of glucose transport after the mantis shrimp. Different letters at the same time showed significantly different $(P<0.05)$. Values are expressed as \pm standard error.

Sumber: Hasil pengolahan data 
Berdasarkan data pada Gambar 2 dapat diartikan bahwa sistem transportasi mempengaruhi kecepatan waktu pulih udang mantis. Hal ini sesuai dengan hasil penelitian Lorenzon et al. (2008), bahwa tingkat glukosa pada hemolymph dipengaruhi oleh sistem transportasi dan waktu pemulihan.

\subsection{Tingkat Kelangsungan Hidup (SR)}

Dari Gambar 3 menunjukkan bahwa tingkat kelangsungan hidup udang mantis pasca transportasi berbeda secara signifikan $(\mathrm{P}<0.05)$, dimana tingkat kelangsungan hidup pada perlakuan TKTM-O2 $(93.3 \pm 1.15 \%)$ lebih tinggi dari pada perlakuan TB $(63.3 \pm 1.53 \%)$.

Tingginya kelangsungan hidup pada perlakuan TKTM-O2 terkait dengan kemampuan udang untuk mengatasi stress yang terjadi selama transportasi, karena pada saat tersebut udang dalam kondisi motil. Proses metabolisme akan berkurang pada saat kondisi motil atau pingsan, sehingga aktivitas fisiologis, kebutuhan oksigen, dan produksi $\mathrm{CO}_{2}$ dalam berespirasi menjadi rendah (Nitibaskara, Wibowo \& Uju, 2006).

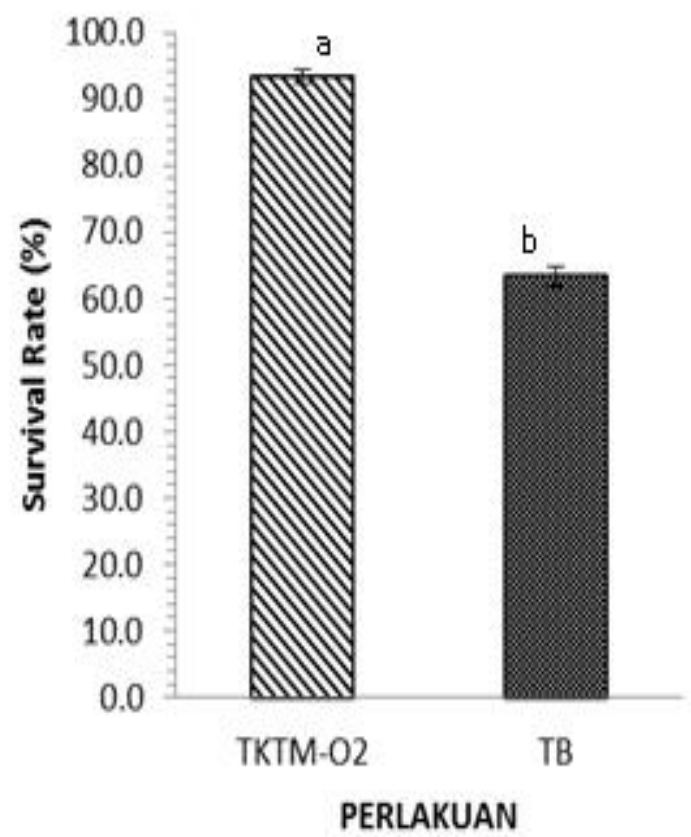

Gambar 3. Tingkat kelangsungan hidup udang mantis pasca transportasi. Nilai dinyatakan \pm sebagai standar error.

Figure 3. Mantis shrimp survival rate after transport. Values are expressed as \pm standard error. Sumber: Hasil analisis
Untuk perlakuan TB yang tingkat kelangsungan hidupnya lebih rendah disebabkan karena udang mantis mengalami stress, hal ini diduga terkait dengan meningkatnya suhu air media transportasi dari $25 \pm 0,58^{\circ} \mathrm{C}$ pada awal transportasi menjadi 30 $\pm 0,58^{\circ} \mathrm{C}$ pada akhir transportasi. Tingginya suhu tersebut menyebabkan aktivitas metabolisme udang mantis meningkat, sehingga konsumsi oksigen juga meningkat, sementara ketersediaan oksigen di dalam media terbatas. Selain itu peningkatan kecepatan berespirasi juga menyumbang dalam penurunan kualitas air media transportasi. Hal ini sesuai dengan pendapat Wibowo (1993), bahwa tingginya suhu media dapat menyebabkan aktivitas metabolisme lobster meningkat, menyebabkan konsumsi oksigen meningkat pula sehingga persediaan oksigen yang terbatas dalan media kemasan akan berkurang dan akhirnya tidak mencukupi kebutuhan dan menyebabkan tingginya tingkat kematian.

Berdasarkan hasil analisis respon stress yang diuji (THC dan glukosa) menunjukkan bahwa stress udang mantis lebih tinggi pada perlakuan TB dari pada perlakuan TKTM-O2. Kondisi tersebut terbukti selama berlangsungnya proses pemulihan/pemeliharaan pasca transportasi, dimana udang mantis pada perlakuan TKTM-O2 lebih cepat pulih dibanding perlakuan TB.

\section{KESIMPULAN DAN SARAN}

\section{Kesimpulan \\ Transportasi sistem kering tanpa media pengisi yang diinjeksi oksigen $\left(\mathrm{TKTM}-\mathrm{O}_{2}\right)$ merupakan transportasi yang paling baik untuk pengangkutan udang mantis (Harpiosquilla raphidea) karena menghasilkan respon stress yang lebih rendah dan waktu pulih yang lebih cepat, serta menghasilkan kelangsungan hidup sebesar 93,3\%.}

\section{Saran}

Perlu kiranya dilakukan pengkajian respon stress terhadap beberapa variabel fisiologi lainnya seperti hormon, produk metabolism.

\section{DAFTAR PUSTAKA}

Berka, R. (1986). The Transport of Live Fish. A Review. EIFAC Tech. Pap. FAO.(48), 52.

Total Hemosit, Glukosa dan Survival Rate Udang Mantis (Harpiosquilla raphidea) Pasca Transportasi dengan Dua Sistem yang Berbeda - M. Yusuf Arifin, Eddy Supriyono dan Widanarni 
Blaxhall, P., and Daisley, K. (1973). Some blood parameters of the rainbow trout I. The Kamloops Variety. J. Fish Biol. 5, 1-8.

Buchanan, K. L. (2000). Stress and The Evolution of Condition-dependent Signal. see front matter (C) 2000 Elsevier Science Ltd. All rights reserved. 15(4).

Cheng, A., Lu, W., and Chen, J. C. (2005). Effect of Water Temperature on The Immune Response of White Shrimp Litopenaeus vannamei to Vibrio alginolyticus. Departement of Aguaculture, National Pingtung University of Science and Technology, Pintung 912, Taiwan.

Dini, L., Kasim, M., dan Palupi, R. D. (2013). Kelimpahan dan komposisi ukuran panjang Udang Ronggeng (Lysiosquilla maculata) pada habitat yang berbeda di perairan Kauduma Desa Petetea'a Kabupaten Buton Utara. Jurnal Mina Laut Indonesia, 1(1), 1-11.

[DKP] Dinas Kelautan \& Perikanan Kabupaten Tanjung Jabung Barat. (2010). Laporan tahunan Dinas Kelautan dan Perikanan Kabupaten Tanjung Jabung Barat Tahun 2009. Tanjung Jabung Barat. Jambi.

Frose, R. (1997). How to transport live fish in plastic bags. Technical Paper FAO. Rome. $4 p$

Hasan, D. (2007). Pengujian transportasi ikan hidup ikan mas (Cyprinus carpio) dan ikan jambal siam (Pangasius sutchi F) dengan metode anestasi. Berkala Perikanan Terubuk, 35(1), 135-146.

Hastuti, S., Mokoginta, I., Dana, D., dan Sutardi, T. (2004). Resistensi terhadap stres dan respons imunitas ikan gurami (Osphronemus Gouramy, Lac.) yang diberi pakan mengandung kromiumragi. Jurnal Ilmu-Ilmu Perairan dan Perikanan Indonesia, 11(1), 15-21.

Jussila, J. (1997). Physiological Responses of Astacid and Parastacid Crayfishes (Crustecea: Decapoda) to Condition of Intensive Culture (Vol. 67). Kuopio University Publications C. Naturan and Environmental Sciences.

Kompas. (2004). Udang Ketak Kuala Tungkal Ditangkarkan di Hongkong. www.kompas. com, Diakses 27 April 2014.

Le Moullac, G., Soyez, C., Sauliner, D., Ansquer, D., Avarre, J., and Levy, P. (1998). The effect of hypoxic stress on the immune response and resistance to vibriosis of the shrimp $\mathrm{P}$. stylirostris. Fish Shellfish Immunol, 8, 621-629.

Leland, J. C., Butchera, P. A., Broadhursta, M .K., Patersonc, B. D., and Mayer, D. G. (2013). Damage and physiological stress to juvenile eastern rock lobster (Sagmariasus verreauxi) discarded after trapping and hand collection. Journal of Fisheries Research, 137, 63-70.

Lorenzon, S., Francese, M., Smith, V. J., and Ferrero, E. A. (2001). Heavy metals affect the circulating haemocyte number in the shrimp Palaemon elegans. Fish Shellfish Immunol, 11, 459-472.

Lorenzon, S., Giulianini, P. G., Martinis, M., and Ferrero, E. A. (2007). Stress effect of different temperatures and air exposure during transport on physiological profiles in the American Lobster Homarus americanus. Journal of Comparative Biochemistry and Physiology, Part A 147, 94-102.

Lorenzon, S., Giulianini, P. G., Libralato, S., Martinis, M., and Ferrero, E. A. (2008). Stress effect of two different transport sistems on the physiological profiles of the crab Cancer pagurus. Journal of Aquaculture, 278, 156-163.

Maharani, G., Sunarti, Triastuti, J. dan Juniastuti, T. (2009). Kerusakan dan jumlah hemosit udang Windu (Penaeus monodon Fab.) yang mengalami zoothamniosis. Jurnal Ilmiah Perikanan dan Kelautan, 1(1), 21-30.

Mashar, A., dan Wardiatno, Y. (2011). Distribusi spasial udang mantis Harpiosquilla raphidea dan Oratosquillina gravieri di Kuala Tungkal, Kabupaten Tanjung Jabung Barat, Provinsi Jambi. Jurnal Pertanian-UMMI, 1(1).

Mashar, A. (2011). Pengelolaan Sumberdaya Udang Mantis (Harpiosquilla raphidea Fabricius, 1978) Berdasarkan Informasi Biologi di Kuala Tungkal Kabupaten Tanjung Jabung Barat, Jambi. Tesis, Sekolah Pasca Sarjana, Institut Pertanian Bogor, Bogor.

McEwen, B. S., and Wingfield, J. C. (2003). The concept of allostasis in biology and biomedicine. Horm. Behav., 43 (1), 2-15.

Nitibaskara, R., Wibowo, S., dan Uju. (2006). Penanganan dan Transportasi Ikan Hidzip untuk Konsumsi. Bogor: Departemen Teknologi Hasil Perairan, Fakultas Perikanan dan Ilmu Kelautan, Institut Pertanian Bogor.

Sahoo, P. K., Das, A., Mohanty, B. K., Pilai, B. R., and Mohanty, J. (2008). Dietary-1,3 glucan improve the immunity and disease resistance of freshwater prawn Macrobrachium rosenbergii Challenged with Aeromonas hydrophyla. Aquaculture Research, 39, 1574-1578.

Suparno, Wibowo, S., Suryaningrum, T.D., da Suherman, M. (1994). Studi penggunaan metoda penurunan suhu bertahap dalam transportasi sistem kering untuk lobster hijau pasir (Panulirus humarus). Jurnal Penelitian Pasca Panen Perikanan, 79, 37-55.

Suryaningrum, Th. D., Utomo, B. S. B., dan Wibowo, S. (2005). Teknologi Penanganan dan Transportasi Krustasea Hidup. Jakarta: Badan Riset Kelautan dan Perikanan.

Suryaningrum, Th. D., Syamidi dan Ikasari. (2007). Teknologi penanganan dan transportasi lobster air tawar. Squalen 2(2), 37-42. 
Suwandi, R., Novriani, A., dan Nurjanah. (2008). Aplikasi rak dalam wadah penyimpanan untuk transportasi lobster air tawar (Cherax Quadricarinatus) tanpa media air. Buletin Teknologi Hasil Perikanan, 11(1).

Verghese, B. (2003). Some Immunobiological Aspects of the Spiny Lobster Panulirus homarus (Linnaeus, 1758). Central Marine Fisheries Research Institute (Indian Council Of Agricultural Research) Kochi-682 014.

Wedemeyer, G. A., and Yasutake, W. T. (1977). Clinical Methods for the Assessment of the Effects of Environmental Stress on Fish Health. (Vol. 89). Washington DC (US) Department of the Interior Fish and Wildlife Service.

Wibowo, S. (1993). Penerapan Teknologi Penanganan dan Transportasi Ikan Hidup di Indonesia. Jakarta: Sub BPPL, Slipi.

Wibowo, S., Setiabudi, E., Suryaningrum, D., dan Sudrajat, Y. (1994). Pengaruh penurunan suhu bertahap terhadap aktivitas lobster hijau pasir (Panulirus humarus). Jurnal Penelitian Pasca Panen Perikanan, (79), 24-36.

Yeh, S.T., Li, C.C., Tsui, W.C., Lin, Y.C., and Chen, J.C. (2010). The protective immunity of white shrimp Litopenaeus vannamei that had been immersed in the hot-water extract of Gracilaria tenuistipitata and subjected to combined stresses of Vibrio alginolyticus injection and temperature change. Fish Sellfish Immunol, 29(2), 271-278.

Zonneveld, N., Huisman, E. A., dan Boon, J. H. (1991). Prinsip-prinsip Budidaya Ikan. Jakarta. PT Gramedia Pustaka Utama. 